FULL TEXT ARTICLE

REVIEW

\title{
Sodium-glucose co-transporter 2 (SGLT2) inhibitors: a growing class of antidiabetic agents
}

\section{Eva M Vivian, PharmD, MS, BC-ADM, CDE}

School of Pharmacy, University of Wisconsin, Madison, WI, USA

\section{Citation}

Vivian EM. Sodium-glucose co-transporter 2 (SGLT2) inhibitors: a growing class of antidiabetic agents. Drugs in Context 2014; 3: 212264. doi: 10.7573/dic.212264

\section{Copyright}

(c) 2014 Vivian EM. Distributed under the terms of the Creative Commons License Deed CC BY NC ND 3.0 which allows anyone to copy, distribute, and transmit the article provided it is properly attributed in the manner specified below. No other uses without permission.

\section{Correct attribution}

Copyright $\odot$ Vivian EM. http://dx.doi.org/10.7573/dic.212264. Published by Drugs in Context under Creative Commons Attributions License Deed CC BY NC ND 3.0.

\section{Article URL}

http://www.drugsincontext.com/sodium-glucose-cotransporter-2-sglt2-inhibitors-growing-class-antidiabetic-agents

\section{Correspondence}

Eva M Vivian, PharmD, MS, BC-ADM, CDE, Associate Professor, School of Pharmacy, University of Wisconsin, Madison, WI, USA.emvivian@pharmacy.wisc.edu

\section{Provenance}

Submitted, externally peer reviewed

\section{Dates}

Submitted: 3 September 2014

Accepted, subject to peer review: 4 September 2014 Peer review comments to author: 18 September 2014 Revised manuscript submitted: 10 November 2014 Publication date: 19 December 2014

\section{Publisher $\&$ contact information}

Drugs in Context is published by Just Medical Media Ltd, Undermount, Rydal, Ambleside, Cumbria, LA22 9LT, UK; ISSN 1740-4398; Just Medical Media Limited is registered in England Number 6891187; VAT GB 945171322

\section{Julia Savory}

Head of Digital Publishing and Submissions Management julia@justmedicalmedia.com; Tel: +44 (0)1242910999

\section{Abbreviations}

$A A C E$, American Association of Clinical Endocrinologists; $A C E I$, angiotensin-converting enzyme inhibitor; $A E$, adverse event; $A R B$, angiotensin receptor blocker; $B P$, blood pressure; CKD, chronic kidney disease; DBP, diastolic blood pressure; DM, diabetes mellitus; eGFR, estimated glomerular filtration rate; EU, European Union; FPG, fasting plasma glucose; GFR, glomerular filtration rate; $\mathrm{HbA}_{1 c^{\prime}}$ glycated hemoglobin; HDL-C, high-density lipoprotein cholesterol; LDL-C, lowdensity lipoprotein cholesterol; PPG, postprandial glucose; SBP, systolic blood pressure; $t_{1 / 2}$, half-life; T2DM, type 2 diabetes mellitus; US, United States 


\section{ENDOCRINOLOGY EDITORIAL BOARD}

\section{Specialist Editor-in-Chief}

\section{Professor Eva M Vivian, PharmD}

Associate Professor, University of Wisconsin-Madison School of Pharmacy, Madison, WI, USA

\section{Specialist Health Economics Editor}

\section{Dr Won Chan Lee, PhD}

Principal, Health Economics and Outcomes Research, IMS

Consulting Group, Alexandria, VA, USA

\section{Specialist Advisor - Epidemiology}

\section{Professor Jennifer Robinson, MD}

Clinical Assistant Professor, Department of Pharmacotherapy, Washington State University College of Pharmacy, Spokane, WA, USA

\section{Specialist editorial board members}

\section{Marlon E Cerf, MD}

Specialist Scientist, Diabetes Discovery Platform, South African Medical Research Council, South Africa

\section{Pamela Daniels, MBA, MPH, PhD}

Epidemiologist, Morehouse School of Medicine, 720 Westview Drive, SW, MRC Annex S-10, Atlanta, GA, USA

\section{Professor Stuart T Haines, PharmD}

Professor and Vice Chair for Clinical Services, Department of Pharmacy Practice and Science, University of Maryland School of Pharmacy, Baltimore, MD, USA; Clinical Pharmacy Specialist, West Palm Beach VA Medical Center, West Palm Beach, FL, USA

\section{Sivaramakrishna Koganti, PhD}

Department of Internal Medicine, Carver College of Medicine, University of lowa, USA

\section{Professor Elaena Quattrocchi, PharmD}

Associate Professor, Division of Pharmacy Practice, Arnold and Marie Schwartz College of Pharmacy and Health Sciences, Staten Island University Hospital, NY, USA

\section{Evan Sisson, PharmD, MHA, CDE}

Virginia Commonwealth University, School of Pharmacy, Virginia, USA

\section{Junhua Yu}

Assistant Professor, Social, Behavioral and Administrative Sciences, Touro University College of Pharmacy, Vallejo, CA, USA

To see the full Drugs in Context Editorial Board, please visit www.drugsincontext.com/editorial-board

\section{Group Editor-in-Chief}

\section{Christopher Blanchette, PhD, MBA}

Associate Dean for Research and Research Associate Professor in the Department of Public Health Sciences at the University of North Carolina and Director of Health Economics \& Outcomes Research at Otsuka America Pharmaceutical Inc, USA

Expert Advisers - Epidemiology and biostatistics

Alex K Exuzides, PhD

Director, ICON Clinical Research Inc, California, USA

\section{Professor Scott L Friedman, MD}

Fishberg Professor of Medicine, Dean for Therapeutic Discovery Chief, Division of Liver Diseases, Mount Sinai School of Medicine, New York, USA

\section{Carl De Moor, PhD}

Senior Principal, Epidemiology and Leader Epidemiology, Safety and Risk Management Center of Excellence Americas, IMS Health Inc, USA

\section{Dr John H Walker, OCT, MBA, PhD}

Professor, Goodman School of Business, Brock University, St Catharines, Ontario, Canada

\section{Expert Adviser - Publication Ethics}

\section{Dr Elizabeth (Liz) Wager}

Publications Consultant, Princes Risborough, UK; Visiting Professor, University of Split School of Medicine, Croatia; Former Chair (2009-2012), Committee on Publication Ethics (COPE)

\section{Editor-in-Chief Emeritus}

Dr George Kassianos, FRCGP, FBHS, FESC, FBGTHA, FAcadMEd, FFTM RCPSGlasg

General Practitioner, Bracknell, Berkshire, UK; President British Global \& Travel Health Association Fellow of the European Society of Cardiology

Specialist Advisor - Clinical Pharmacology

Dr Richard White, MA, PhD

Consulting Partner and Director, Oxford PharmaGenesis Ltd, UK 


\section{REVIEW}

\section{Sodium-glucose co-transporter 2 (SGLT2) inhibitors: a growing class of antidiabetic agents}

Eva M Vivian, PharmD, MS, BC-ADM, CDE

School of Pharmacy, University of Wisconsin, Madison, WI, USA

\section{Citation}

Vivian EM. Sodium-glucose co-transporter 2 (SGLT2) inhibitors: a growing class of antidiabetic agents. Drugs in Context 2014;

3: 212264 . doi: $10.7573 /$ dic. 212264

\begin{abstract}
Although several treatment options are available to reduce hyperglycemia, only about half of individuals with diagnosed diabetes mellitus (DM) achieve recommended glycemic targets. New agents that reduce blood glucose concentrations by novel mechanisms and have acceptable safety profiles are needed to improve glycemic control and reduce the complications associated with type 2 diabetes mellitus (T2DM). The renal sodium-glucose co-transporter 2 (SGLT2) is responsible for reabsorption of most of the glucose filtered by the kidney. Inhibitors of SGLT2 lower blood glucose independent of the secretion and action of insulin by inhibiting renal reabsorption of glucose, thereby promoting the increased urinary excretion of excess glucose. Canagliflozin, dapagliflozin, and empagliflozin
\end{abstract}

are SGLT2 inhibitors approved as treatments for T2DM in the United States, Europe, and other countries. Canagliflozin, dapagliflozin, and empagliflozin increase renal excretion of glucose and improve glycemic parameters in patients with T2DM when used as monotherapy or in combination with other antihyperglycemic agents. Treatment with SGLT2 inhibitors is associated with weight reduction, lowered blood pressure, and a low intrinsic propensity to cause hypoglycemia. Overall, canagliflozin, dapagliflozin, and empagliflozin are well tolerated. Cases of genital infections and, in some studies, urinary tract infections have been more frequent in canagliflozin-, dapagliflozin-, and empagliflozin-treated patients compared with those receiving placebo. Evidence from clinical trials suggests that SGLT2 inhibitors are a promising new treatment option for T2DM.

Keywords: administration, oral; canagliflozin; dapagliflozin; diabetes mellitus, type 2; drug therapy; empagliflozin; antidiabetic agents; sodium-glucose co-transporter 2

\section{Introduction}

Type 2 diabetes mellitus (T2DM) accounts for $90 \%$ to $95 \%$ of all cases of diagnosed diabetes mellitus (DM) in adults [1]. Chronic hyperglycemia is the hallmark of T2DM and is associated with the development of microvascular complications, including retinopathy, neuropathy, and nephropathy [2].

Control of blood glucose is fundamental to T2DM management. The American Diabetes Association/European Association for the Study of Diabetes and the American Association of Clinical Endocrinologists (AACE) recommend glycated hemoglobin $\left(\mathrm{HbA}_{1 c}\right)$ levels $<7.0 \%$ and $\leq 6.5 \%$, respectively, for most patients, but that glycemic goals should be individualized for each patient [3,4]. Lifestyle changes such as diet, exercise, and weight loss are typically recommended for patients with T2DM, but most patients require pharmacotherapy to achieve glycemic goals [5].
Despite the availability of several antihyperglycemic agents, only $53 \%$ of patients with DM achieve $\mathrm{HbA}_{1 c}<7.0 \%$ [6].

Therefore, there is a need for new therapeutic options with innovative mechanisms of action and acceptable safety profiles to improve glycemic control in patients with T2DM.

A new approach to reduce plasma glucose concentrations in patients with T2DM is to inhibit glucose reabsorption by the kidney [7]. Recently, several members of a new class of drugs, sodium-glucose co-transporter 2 (SGLT2) inhibitors, that act via this mechanism have been approved as therapy for T2DM. Here, I discuss the role of the kidney and SGLT2 in glucose homeostasis, and the mechanism of action of SGLT2 inhibitors. Also, I summarize the efficacy and safety of canagliflozin, dapagliflozin, and empagliflozin. These SGLT2 inhibitors have been approved in the United States (US), European Union (EU), and other countries for the treatment of patients with T2DM. 
Figure 1. Glucose reabsorption by the kidney. Normally, SGLT2 reabsorbs most of the glucose filtered by the kidney. SGLT2 inhibitors reduce renal reabsorption of glucose, resulting in increased glucose excretion and lowering of plasma glucose concentration.

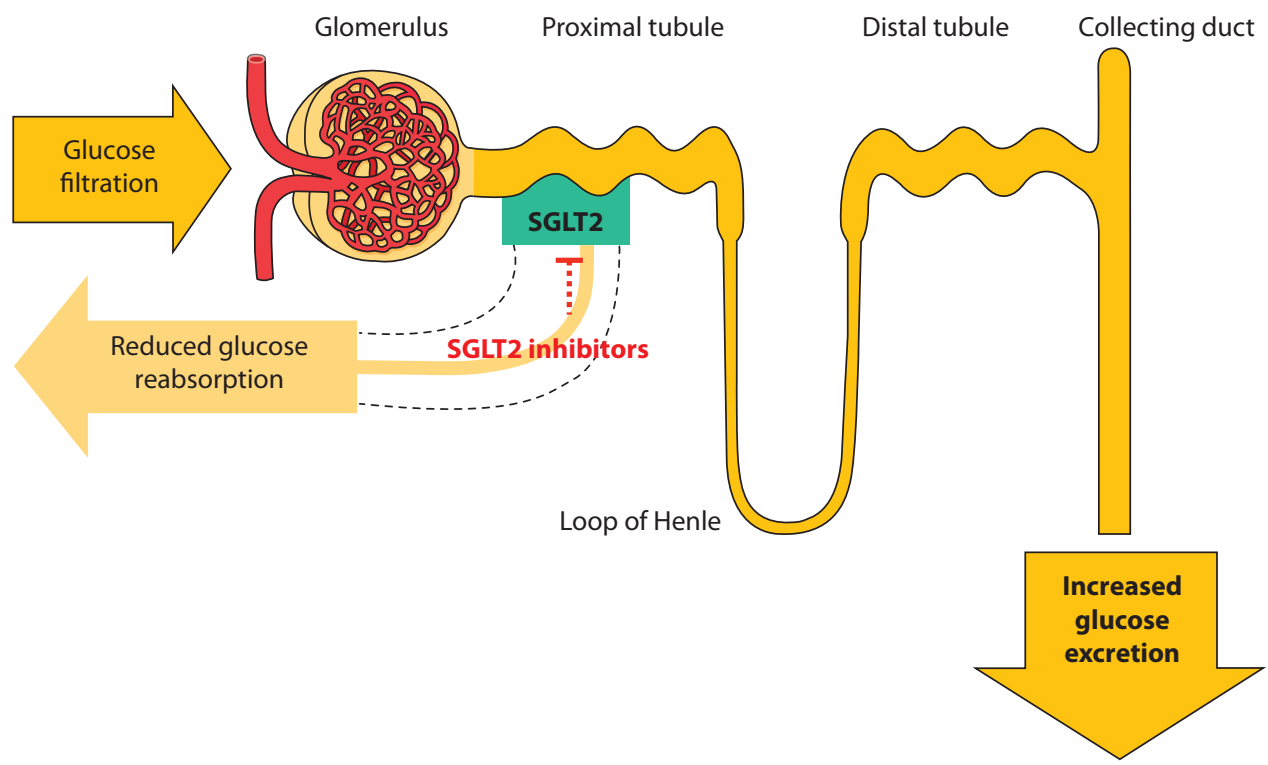

Reproduced with permission from Freeman JS. Review of insulin-dependent and insulin-independent agents for treating patients with type 2 diabetes mellitus and potential role for sodium-glucose co-transporter 2 inhibitors. Postgrad Med 2013;125(3):214-26.

SGLT2, sodium-glucose co-transporter 2

\section{Role of the kidney in glucose homeostasis}

The kidney contributes to glucose homeostasis primarily by glucose reabsorption to the circulation. Glucose is filtered freely by the kidneys. In healthy individuals, almost all of it is reabsorbed by the kidneys [8]. Glucose reabsorption by the kidney is mediated by specific glucose transport proteins, in particular SGLT2, which is responsible for most of the glucose reabsorption by the kidney (Figure 1) [8]. In individuals with T2DM, the renal capacity to reabsorb glucose is increased [9] and contributes to the already increased plasma glucose concentrations. Moreover, the plasma glucose concentration at which renal excretion of glucose occurs (i.e., the threshold) is also elevated in T2DM [9]. The increased threshold and capacity to reabsorb glucose in T2DM may be the result of upregulation of expression of SGLT2 in the proximal tubule [10]. Therefore, inhibition of glucose reabsorption and augmentation of renal excretion of glucose represents a novel mechanism to reduce plasma glucose that is complementary to the mechanisms of current drug classes for T2DM.

\section{Inhibition of SGLT2}

SGLT2 inhibitor-induced glucose excretion is proportional to the amount of glucose filtered by the kidneys, which is a function of the glomerular filtration rate (GFR) and plasma glucose concentration [11]. This phenomenon results in several important considerations regarding the mechanism of action of SGLT2 inhibitors. First, increased plasma glucose concentration (as observed in DM) leads to increased glucose filtration (dependent on the GFR) and may allow greater excretion of glucose with SGLT2 inhibition. Second, because the mechanism of action of SGLT2 inhibitors is independent of the secretion or action of insulin and diminishes as patients' plasma glucose concentrations decrease, the intrinsic risk of hypoglycemia with this drug class is low [12]. Furthermore, glucose excretion as a consequence of SGLT2 inhibition results in a loss of calories that leads to a decrease in body weight and fat mass [13,14], an additional benefit that addresses two of the underlying factors in the pathogenesis of T2DM: excessive caloric intake and increased body weight [15]. SGLT2 inhibitors also have a mild diuretic effect [16], with modest lowering of blood pressure (BP) in patients with T2DM [14,17].

\section{Canagliflozin}

Canagliflozin (Invokana*) was approved in the US and EU in 2013 for the treatment of T2DM. The recommended starting dose is $100 \mathrm{mg}$ once daily, which can be increased to $300 \mathrm{mg}$ once daily in patients tolerating canagliflozin who have an estimated GFR (eGFR) $\geq 60 \mathrm{~mL} / \mathrm{min} / 1.73 \mathrm{~m}^{2}$ and who

*Registered trademark of Janssen Pharmaceuticals, Inc., Titusville, NJ, USA 
require additional glycemic control [18]. A maximum dose of $100 \mathrm{mg}$ is recommended for patients with an eGFR 45 to $<60 \mathrm{~mL} / \mathrm{min} / 1.73 \mathrm{~m}^{2}$; canagliflozin should not be used in patients with an eGFR $<45 \mathrm{~mL} / \mathrm{min} / 1.73 \mathrm{~m}^{2}$ [18]. After oral administration of canagliflozin to individuals with T2DM, maximum plasma concentrations were obtained in 1.5 to $2 \mathrm{~h}$, with a mean halflife $\left(t_{1 / 2}\right)$ of 14 to $16 \mathrm{~h}$, which is consistent with once-daily dosing [19]. Canagliflozin inhibits renal reabsorption of glucose [20] and has some affinity for SGLT1 [21], the major intestinal glucose transporter [22]. At a dose of $300 \mathrm{mg}$ taken before a meal, canagliflozin inhibits SGLT2, but may also inhibit SGLT1 in the intestine and delay postprandial glucose (PPG) absorption [23].

Coadministration of uridine $5^{\prime}$-disphosphate glucuronosyltransferase inducers such as rifampin decreases exposure to canagliflozin, whereas canagliflozin increases exposure to digoxin [18]. Patients taking canagliflozin with digoxin should be monitored appropriately.

\section{Efficacy}

In clinical trials, canagliflozin at $100 \mathrm{mg} / \mathrm{d}$ and $300 \mathrm{mg} / \mathrm{d}$ significantly reduced $\mathrm{HbA}_{1 \mathrm{c}}$ by $0.37 \%$ to $1.16 \%$, and fasting plasma glucose (FPG) by 25 to $43 \mathrm{mg} / \mathrm{dL}$ compared with placebo when used as monotherapy or as add-on therapy to commonly used antidiabetic medications (Table 1). Canagliflozin also decreased PPG compared with placebo or comparator [24,25]. The favorable effect on glycemic parameters was accompanied by reductions in body weight of 1.9 to $3.3 \mathrm{~kg}$. Canagliflozininduced weight reduction was largely the result of a reduction in fat mass [14]. In these clinical trials, placebo- or comparatorcorrected reductions in systolic blood pressure (SBP) and diastolic blood pressure (DBP) of up to $-7 \mathrm{mmHg}$ and $-3 \mathrm{mmHg}$, respectively, were observed with canagliflozin.

When compared with glimepiride as add-on therapy to metformin, canagliflozin $100 \mathrm{mg} / \mathrm{d}$ was noninferior to glimepiride and at $300 \mathrm{mg} / \mathrm{d}$ was superior to glimepiride in reducing $\mathrm{HbA}_{1 c}$ after 52 weeks of treatment (Table 1) [14]. The reduction in FPG with canagliflozin was slightly greater than that seen with glimepiride. Body weight decreased with both canagliflozin doses $(-3.7 \mathrm{~kg}$ [-4.4\%] and $-4.0 \mathrm{~kg}$ [-4.7\%]; $P<0.0001$ for both doses vs glimepiride), whereas there was a small increase $(0.7 \mathrm{~kg}[1.0 \%])$ with glimepiride.

In patients receiving background metformin therapy, canagliflozin $100 \mathrm{mg} / \mathrm{d}$ for 52 weeks (26-week placeboand sitagliptin-controlled period followed by a 26-week sitagliptin-controlled period [placebo group switched to sitagliptin]) was noninferior and $300 \mathrm{mg} / \mathrm{d}$ was superior to sitagliptin in reducing $\mathrm{HbA}_{1 \mathrm{c}}$ (Table 1) [24]. At week 26, canagliflozin 100 and $300 \mathrm{mg} / \mathrm{d}$ significantly reduced $\mathrm{HbA}_{1 \mathrm{c}}$ compared with placebo $(-0.79 \%$ and $-0.94 \%$, respectively, vs $-0.17 \%$ for placebo; $P<0.001)$. Both doses of canagliflozin also significantly reduced body weight $(P<0.001)$, FPG $(P<0.001)$, and SBP (difference from sitagliptin, -2.9 and $-4.0 \mathrm{mmHg}$; $P<0.001)$ to a greater extent than that seen with sitagliptin at
52 weeks. In older patients (mean age, 64 years) with T2DM taking antihyperglycemic medications, placebo-corrected changes from baseline to 26 weeks in $\mathrm{HbA}_{1 c}$ were $-0.57 \%$ and $-0.70 \%$ (both $P<0.001$ vs placebo) and in FPG were -26 and $-28 \mathrm{mg} / \mathrm{dL}$ (both $P<0.001$ vs placebo) with canagliflozin 100 and $300 \mathrm{mg} / \mathrm{d}$, respectively. More patients receiving canagliflozin achieved $\mathrm{HbA}_{1 \mathrm{c}}<7 \%$ (48\% and 59\%, respectively; $P<0.001$ vs placebo) than those receiving placebo (28\%) [26]. Placebo-corrected mean changes in body weight were -2.1 and $-2.7 \mathrm{~kg}$ for canagliflozin ( $P<0.001$ for both doses). Compared with placebo, SBP was reduced by 5 and $8 \mathrm{mmHg}$ with canagliflozin ( $P<0.001$ for both doses).

The mechanism of action of SGLT2 inhibitors is dependent on renal filtration of glucose. Hence, the effect of canagliflozin was assessed in patients with chronic kidney disease (CKD) (mean eGFR, $\left.39.4 \mathrm{~mL} / \mathrm{min} / 1.73 \mathrm{~m}^{2}\right)$. Mean changes from baseline $\mathrm{HbA}_{\mathrm{lc}}$ relative to placebo were $-0.30 \%(P<0.05)$ and $-0.40 \%(P<0.001)$ with canagliflozin 100 and $300 \mathrm{mg} / \mathrm{d}$, respectively [27], which were less than those seen in patients with normal or near-normal kidney function [24,25]. Changes in FPG appeared greater with canagliflozin than with placebo, but differences were not analyzed statistically. Body weight was reduced with canagliflozin relative to placebo (-1.4 and $-1.6 \mathrm{~kg}$ for canagliflozin). Both doses of canagliflozin were associated with greater decreases from baseline compared with placebo in SBP $(-6.1$ and -6.4 vs $-0.3 \mathrm{mmHg}$ ) and DBP ( -2.6 and -3.5 vs $-1.4 \mathrm{mmHg})$.

\section{Safety}

In clinical trials, canagliflozin was, in general, well tolerated. Genital infections were more frequent with canagliflozin than with placebo, especially in women (Table 2) [14,24-26,28]. In most studies, osmotic diuresis-related adverse events (AEs; e.g. pollakiuria and polyuria) were increased with canagliflozin compared with placebo [14,24-26,28]. Canagliflozin may cause hyperkalemia, especially in patients with moderate renal impairment (eGFR 45 to $<60 \mathrm{~mL} / \mathrm{min} / 1.73 \mathrm{~m}^{2}$ ) and in patients taking drugs that affect potassium excretion, such as potassium-sparing diuretics or inhibitors of the reninangiotensin-aldosterone system [29]. Volume-related AEs (e.g. postural dizziness and orthostasis) were modestly increased with canagliflozin in some studies $[26,28]$. Small, acute decreases in the eGFR with canagliflozin have been reported in patients with T2DM and normal renal function [14] and in those with CKD [27]. Events of hypoglycemia were infrequent and occurred similarly with canagliflozin and placebo in most studies (Table 2). Hypoglycemia AEs increased when canagliflozin was added to insulin therapy.

Canagliflozin increased low-density lipoprotein cholesterol (LDL-C) by $2 \%$ to $12 \%$ compared with placebo or comparator and high-density lipoprotein cholesterol (HDL-C) by $1 \%$ to $9 \%$. Modest and variable reductions in triglycerides were noted $[14,24-26,28]$. In a pool of four placebo-controlled trials, canagliflozin increased LDL-C relative to placebo by $4.5 \%$ and $8.0 \%$ at 100 and $300 \mathrm{mg} / \mathrm{d}$, respectively [18]. 


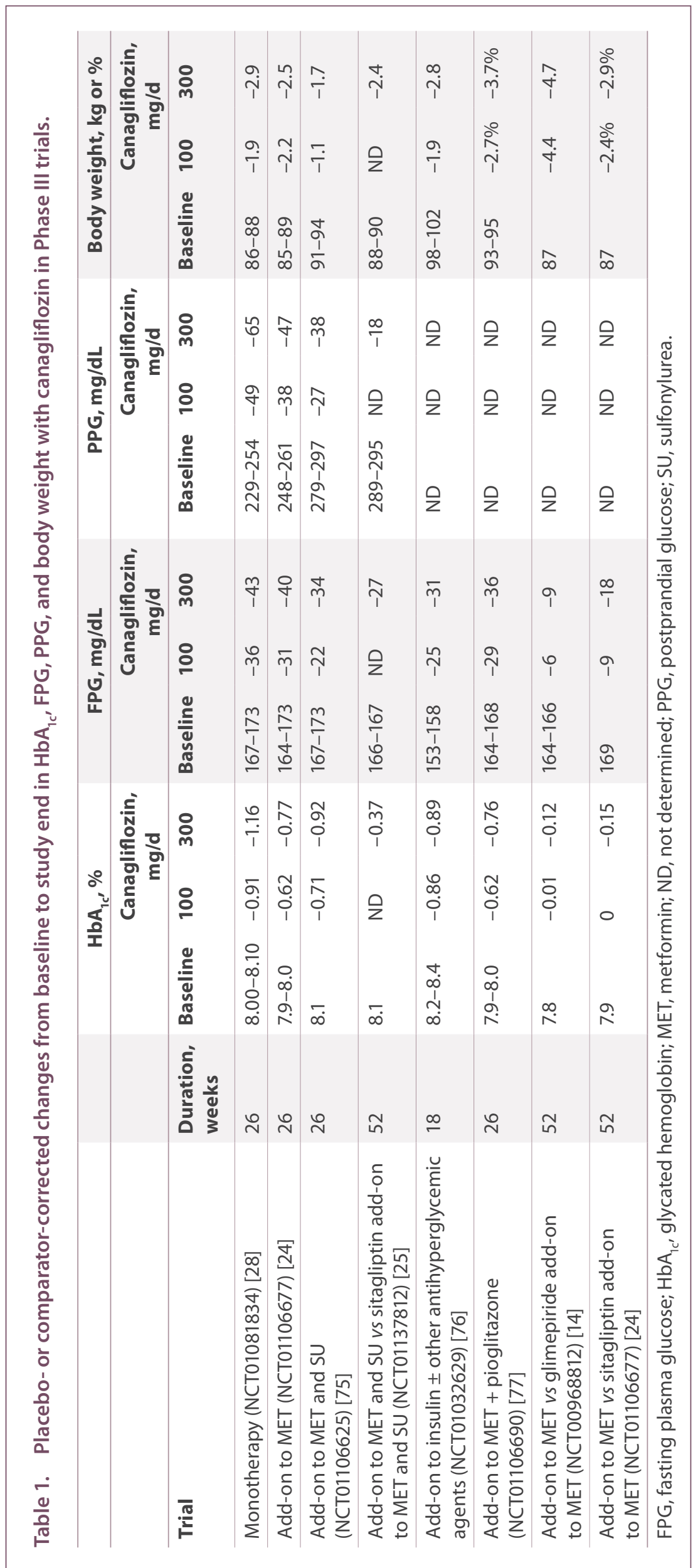


Table 2. Adverse events, including genital infections and urinary tract infections and hypoglycemia,* with canagliflozin in Phase III trials.

\begin{tabular}{|c|c|c|c|c|c|}
\hline \multirow[b]{3}{*}{ Trial } & \multirow[b]{3}{*}{$\begin{array}{l}\text { Duration, } \\
\text { weeks }\end{array}$} & \multirow[b]{3}{*}{ AE } & \multicolumn{3}{|c|}{ Patients, \% } \\
\hline & & & \multirow[b]{2}{*}{$\begin{array}{l}\text { Placebo or } \\
\text { control }\end{array}$} & \multicolumn{2}{|c|}{$\begin{array}{c}\text { Canagliflozin } \\
\text { mg/d }\end{array}$} \\
\hline & & & & 100 & 300 \\
\hline \multirow[t]{4}{*}{ Monotherapy (NCT01081834) [28] } & 26 & $\geq 1 \mathrm{AE}$ & 53 & 61 & 60 \\
\hline & & Genital & 2 & 6 & 7 \\
\hline & & Urinary & 4 & 7 & 5 \\
\hline & & Hypoglycemia & 3 & 4 & 3 \\
\hline \multirow{4}{*}{$\begin{array}{l}\text { Add-on to MET and SU } \\
\text { (NCT01106625) [75] }\end{array}$} & 26 & $\geq 1 \mathrm{AE}$ & 45 & 50 & 56 \\
\hline & & Genital & 0 & 3 & 3 \\
\hline & & Urinary & 3 & 3 & 4 \\
\hline & & Hypoglycemia & 10 & 22 & 27 \\
\hline \multirow{4}{*}{$\begin{array}{l}\text { Add-on to MET and SU vs sitagliptin add-on } \\
\text { to MET and SU (NCT01137812) [25] }\end{array}$} & 52 & $\geq 1 \mathrm{AE}$ & 78 & ND & 77 \\
\hline & & Genital & 2 & ND & 12 \\
\hline & & Urinary & 6 & ND & 4 \\
\hline & & Hypoglycemia & 41 & ND & 43 \\
\hline \multirow{4}{*}{$\begin{array}{l}\text { Add-on to insulin } \pm \text { other antihyperglycemic } \\
\text { agents (NCT01032629) [76] }\end{array}$} & 18 & $\geq 1 \mathrm{AE}$ & 53 & 62 & 67 \\
\hline & & Genital & 3 & 12 & 14 \\
\hline & & Urinary & 1 & 5 & 4 \\
\hline & & Hypoglycemia & 25 & 42 & 43 \\
\hline \multirow{4}{*}{$\begin{array}{l}\text { Add-on to MET + pioglitazone } \\
\text { (NCT01106690) [77] }\end{array}$} & 52 & $\geq 1 \mathrm{AE}$ & 77 & 70 & 76 \\
\hline & & Genital & 3 & 8 & 12 \\
\hline & & Urinary & 8 & 5 & 8 \\
\hline & & Hypoglycemia & 6 & 4 & 6 \\
\hline \multirow{4}{*}{$\begin{array}{l}\text { Add-on to MET vs glimepiride add-on to MET } \\
\text { (NCT00968812) [14] }\end{array}$} & 52 & $\geq 1 \mathrm{AE}$ & 69 & 64 & 69 \\
\hline & & Genital & 2 & 9 & 11 \\
\hline & & Urinary & 5 & 6 & 6 \\
\hline & & Hypoglycemia & 34 & 6 & 5 \\
\hline \multirow{4}{*}{$\begin{array}{l}\text { Add-on to MET vs sitagliptin add-on to MET } \\
\text { (NCT01106677) [24] }\end{array}$} & 52 & $\geq 1 \mathrm{AE}$ & 67 & 72 & 63 \\
\hline & & Genital & 1 & 8 & 7 \\
\hline & & Urinary & 7 & 8 & 5 \\
\hline & & Hypoglycemia & 3 & 7 & 7 \\
\hline
\end{tabular}

*Documented hypoglycemia defined by fingerstick or plasma glucose $\leq 70 \mathrm{mg} / \mathrm{dL}$, irrespective of symptoms and episodes of severe hypoglycemia necessitating assistance or resulting in seizures or loss of consciousness.

$A E$, adverse event; MET, metformin; ND, not determined; SU, sulfonylurea.

\section{Dapagliflozin}

Dapagliflozin (Farxiga $\left.{ }^{\dagger}\right)$, a highly selective inhibitor of SGLT2 [21], was approved for the treatment of T2DM in the EU and other countries in 2012 and in the US in 2014. In the US, the recommended starting dose is $5 \mathrm{mg}$ once daily, which can be increased to $10 \mathrm{mg}$ once daily in patients tolerating dapagliflozin and who require additional glycemic control [30]. In the EU, the recommended starting dose is $10 \mathrm{mg}$ [31].

${ }^{\dagger}$ Registered trademark of AstraZeneca, Wilmington, DE, USA
Kidney function should be assessed before initiating dapagliflozin, and it should not be used in patients with an eGFR $<60 \mathrm{~mL} / \mathrm{min} / 1.73 \mathrm{~m}^{2}$. Also, dapagliflozin should be discontinued if the eGFR persistently falls below $60 \mathrm{~mL} / \mathrm{min} / 1.73 \mathrm{~m}^{2}$ [30].

Dapagliflozin is absorbed rapidly after oral administration [32], with a mean $t_{1 / 2}$ of $\approx 14 \mathrm{~h}$ [33], which is consistent with oncedaily dosing. A high-fat meal does not affect overall systemic exposure to dapagliflozin, thus allowing for administration with or without food [34]. 
Coadministration of dapagliflozin with metformin, glimepiride, pioglitazone, or sitagliptin had no effect on the maximum plasma concentration or area under the plasma concentration compared with time curve of dapagliflozin. In addition, dapagliflozin did not affect the pharmacokinetics of the coadministered drugs [35]. Similarly, no meaningful drug-drug interactions were noted between dapagliflozin and simvastatin, valsartan, warfarin, or digoxin [36].

\section{Efficacy}

In 24-week Phase III clinical trials, dapagliflozin reduced mean $\mathrm{HbA}_{1 \mathrm{c}}$ at the approved doses of 5 and $10 \mathrm{mg} / \mathrm{d}(0.40 \%-0.54 \%$ and $0.50 \%-0.68 \%$, respectively) compared with placebo in patients with T2DM when used as monotherapy or as add-on therapy to metformin, glimepiride, pioglitazone, sitagliptin, or insulin (Table 3). In these trials, dapagliflozin reduced FPG by 15 to $28 \mathrm{mg} / \mathrm{dL}$ compared with placebo. In most of these placebo-controlled trials, dapagliflozin significantly reduced body weight by $\leq 2.0 \mathrm{~kg}$ compared with placebo. As with canagliflozin, the reduction in body weight with dapagliflozin appeared to be largely the result of a reduction in fat mass [13]. Effects of dapagliflozin on glycemic parameters and body weight were maintained for $>2$ years [37-39].

In one study, dapagliflozin $10 \mathrm{mg} / \mathrm{d}$ was compared with the sulfonylurea glipizide as add-on therapy to metformin in patients with T2DM that was inadequately controlled with metformin [40]. The adjusted mean change from baseline in $\mathrm{HbA}_{1 \mathrm{c}}$ at 52 weeks between dapagliflozin and glipizide treatment groups was identical (-0.52\%; Table 3). Both drugs reduced FPG to a similar extent. Dapagliflozin reduced mean body weight by $3.2 \mathrm{~kg}$ ( $P<0.0001$ vs glipizide), whereas glipizide increased body weight by $1.4 \mathrm{~kg}$.

Two randomized, 24-week, active-control trials examined the effects of dapagliflozin 5 and $10 \mathrm{mg} / \mathrm{d}$ combined with metformin XR (most patients received $2000 \mathrm{mg} / \mathrm{d}$ ) as initial therapy in treatment-naïve patients with T2DM [41]. Dapagliflozin 5 and $10 \mathrm{mg} / \mathrm{d}$ plus metformin XR were more effective than either drug alone in reducing mean $\mathrm{HbA}_{1 c}$ $(P<0.0001$; Table 3). Similarly, dapagliflozin 5 and $10 \mathrm{mg} / \mathrm{d}$ plus metformin $X R$ were more effective in reducing mean FPG than either drug alone $(P<0.0001)$. Combinations were also more effective in reducing body weight than metformin alone $(P<0.0001)$. In a prespecified comparison, dapagliflozin $10 \mathrm{mg}$ was noninferior to metformin $\mathrm{XR}$ in reducing $\mathrm{HbA}_{1 \mathrm{c}}$ and superior to metformin XR in reducing FPG and body weight.

In older patients (mean age, 63-64 years) with T2DM and cardiovascular disease [42] or T2DM and cardiovascular disease and hypertension [43], changes from baseline compared with placebo at 24 weeks in $\mathrm{HbA}_{1 \mathrm{c}}(-0.3 \%$ vs $0.1 \%$ with placebo $[P<0.001]$ and $-0.4 \%$ vs $0.1 \%[P<0.01]$, respectively), body weight $(-2.5$ vs $-0.6 \mathrm{~kg}[P<0.001]$ and $-2.6 \%$ vs $-0.3 \%[P<0.01])$, and SBP $(-2.7$ vs $0.3 \mathrm{mmHg}[P<0.001]$ and -3.0 vs $-1.0 \mathrm{mmHg}$ $[P<0.01])$ were greater with dapagliflozin than with placebo.
In addition, more patients in the dapagliflozin groups than in the placebo groups $(10.0 \%$ vs $1.9 \%$ with placebo $[P<0.001]$ and $11.7 \%$ vs $0.9 \%[P<0.0001])$ achieved a three-item coprimary end point of reduction of $\mathrm{HbA}_{1 \mathrm{c}} \geq 0.5 \%$, reduction of body weight $\geq 3 \%$, and reduction of SBP $\geq 3 \mathrm{mmHg}$. These findings suggest that dapagliflozin improves glycemic control and body weight in older patients with advanced T2DM and cardiovascular disease.

The effect of dapagliflozin on $\mathrm{HbA}_{1 c}$ was assessed in patients with T2DM and moderate renal impairment ( $>90 \%$ of patients had an eGFR of 30-59 mL/min/1.73 m²) [44]. After 24 weeks of treatment, mean decreases from baseline in $\mathrm{HbA}_{1 c}$ were similar for placebo $(-0.32 \%)$ and dapagliflozin 5 and $10 \mathrm{mg}$ $(-0.41 \%$ and $-0.44 \%$, respectively). FPG increased with placebo (8.4 mg/dL) but decreased with dapagliflozin (-5.2 and $-0.6 \mathrm{mg} / \mathrm{dL}$ ). Mean changes from baseline in body weight for dapagliflozin were -1.3 and $-1.7 \mathrm{~kg}$ compared with $+0.7 \mathrm{~kg}$ for placebo. A pharmacodynamic study in patients with T2DM also suggested that dapagliflozin may have reduced efficacy in patients with moderate (creatinine clearance, $30-50 \mathrm{~mL} / \mathrm{min}$ ) to severe $(<30 \mathrm{~mL} / \mathrm{min})$ renal impairment [45]. Dapagliflozin is not recommended for use in patients with an eGFR $<60 \mathrm{~mL} / \mathrm{min} / 1.73 \mathrm{~m}^{2}$ and is contraindicated in patients with an eGFR $<30 \mathrm{~mL} / \mathrm{min} / 1.73 \mathrm{~m}^{2}$ [44].

BP was assessed as a safety or exploratory end point in the aforementioned Phase III trials. Dapagliflozin treatment resulted in placebo-corrected reductions in SBP of $\leq 5 \mathrm{mmHg}$ and in DBP of $\leq 4 \mathrm{mmHg}$ [46-50]. Despite these reductions in $\mathrm{BP}$, no substantial increases in orthostatic hypotension events were reported with dapagliflozin in these studies $[46,47,50]$.

Two double-blind, randomized, placebo-controlled, 12-week studies assessed the effects of dapagliflozin $10 \mathrm{mg} / \mathrm{d}$ on seated SBP in patients with T2DM and hypertension and inadequate glycemic $\left(\mathrm{HbA}_{1 c^{\prime}} 7.0 \%-10.5 \%\right)$ and BP (seated SBP/DBP, 140-164/85-104 mmHg) control despite receiving glucoselowering drugs and an angiotensin-converting enzyme inhibitor (ACEI) or an angiotensin receptor blocker (ARB) [51] or an ACEI/ARB plus a second antihypertensive drug [52]. In one study, dapagliflozin significantly reduced $\mathrm{HbA}_{1 c}$ (difference vs placebo, $-0.46 \% ; P<0.0001)$ and seated SBP $(-3 \mathrm{mmHg}$, $P=0.001$ ) [51]. Similar responses to dapagliflozin (difference vs placebo: $\mathrm{HbA}_{1 c^{\prime}}-0.61 \%[P<0.0001]$; seated $\mathrm{SBP},-4 \mathrm{mmHg}$ $[P=0.0002])$ were observed in the other study [52]. There were no marked effects of dapagliflozin on serum electrolytes or on the GFR. These studies showed that dapagliflozin consistently lowered BP in patients with T2DM and hypertension, and improved glycemic parameters in patients with inadequate glycemic control.

\section{Safety}

In Phase III trials, AEs reported with dapagliflozin were, in general, mild to moderate and, except for infections of the genital tract and urinary tract, were reported at a similar frequency as with placebo. In patients with T2DM and 


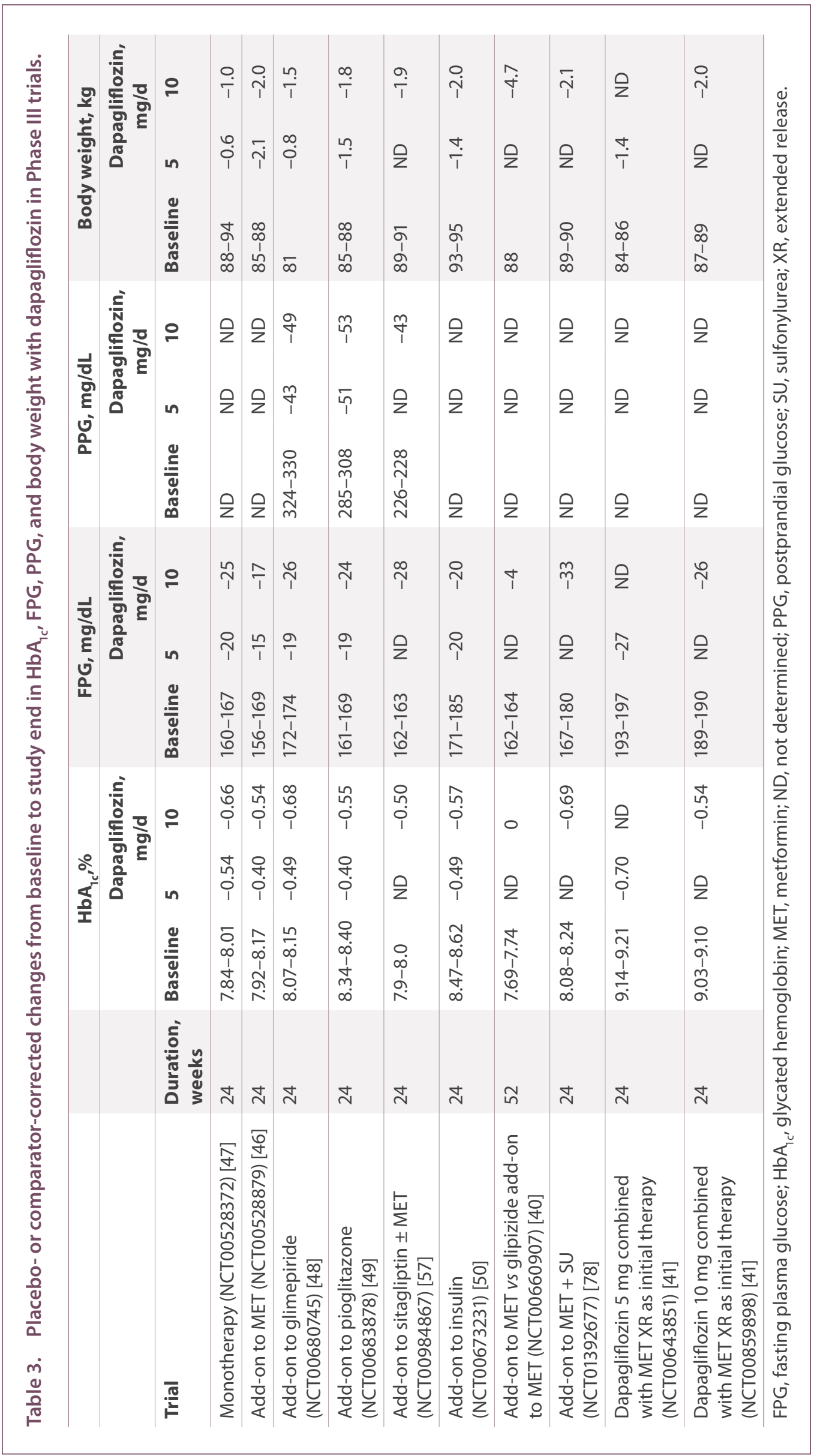


Table 4. Adverse events, including genital infections and urinary tract infections and hypoglycemia,* with dapagliflozin in Phase III trials.

\begin{tabular}{|c|c|c|c|c|c|}
\hline \multirow[b]{3}{*}{ Trial } & \multirow[b]{3}{*}{$\begin{array}{l}\text { Duration, } \\
\text { weeks }\end{array}$} & \multirow[b]{3}{*}{ AE } & \multirow[b]{3}{*}{$\begin{array}{l}\text { Placebo or } \\
\text { control }\end{array}$} & \multirow{2}{*}{\multicolumn{2}{|c|}{$\begin{array}{c}\text { Patients, } \% \\
\text { Dapagliflozin, } \mathrm{mg} / \mathrm{d}\end{array}$}} \\
\hline & & & & & \\
\hline & & & & 5 & 10 \\
\hline \multirow[t]{4}{*}{ Monotherapy (NCT00528372) [47] } & 24 & $\geq 1 \mathrm{AE}$ & 60 & 58 & 69 \\
\hline & & Genital & 1 & 8 & 13 \\
\hline & & Urinary & 4 & 13 & 6 \\
\hline & & Hypoglycemia & 3 & 0 & 3 \\
\hline \multirow[t]{4}{*}{ Add-on to MET (NCT00528879) [46] } & 24 & $\geq 1 \mathrm{AE}$ & 64 & 69 & 73 \\
\hline & & Genital & 5 & 13 & 9 \\
\hline & & Urinary & 8 & 7 & 8 \\
\hline & & Hypoglycemia & 3 & 4 & 4 \\
\hline \multirow[t]{4}{*}{ Add-on to glimepiride (NCT00680745) [48] } & 24 & $\geq 1 \mathrm{AE}$ & 47 & 48 & 50 \\
\hline & & Genital & 1 & 6 & 7 \\
\hline & & Urinary & 6 & 7 & 5 \\
\hline & & Hypoglycemia & 5 & 7 & 8 \\
\hline \multirow[t]{4}{*}{ Add-on to pioglitazone (NCT00683878) [49] } & 24 & $\geq 1 \mathrm{AE}$ & 67 & 68 & 71 \\
\hline & & Genital & 3 & 9 & 9 \\
\hline & & Urinary & 8 & 9 & 5 \\
\hline & & Hypoglycemia & 1 & 2 & 0 \\
\hline \multirow[t]{4}{*}{ Add-on to sitagliptin \pm MET (NCT00984867) [57] } & 24 & $\geq 1 \mathrm{AE}$ & 48 & ND & 53 \\
\hline & & Genital & $<1$ & ND & 8 \\
\hline & & Urinary & 4 & ND & 5 \\
\hline & & Hypoglycemia & 3 & ND & 2 \\
\hline \multirow[t]{4}{*}{ Add-on to insulin (NCT00673231) [50] } & 24 & $\geq 1 \mathrm{AE}$ & 73 & 72 & 74 \\
\hline & & Genital & 3 & 10 & 11 \\
\hline & & Urinary & 5 & 11 & 10 \\
\hline & & Hypoglycemia & 52 & 56 & 54 \\
\hline \multirow{4}{*}{$\begin{array}{l}\text { Add-on to MET vs glipizide add-on to MET } \\
\text { (NCT00660907) [40] }\end{array}$} & 52 & $\geq 1 \mathrm{AE}$ & 78 & ND & 78 \\
\hline & & Genital & 3 & ND & 12 \\
\hline & & Urinary & 6 & ND & 11 \\
\hline & & Hypoglycemia & 41 & ND & 4 \\
\hline \multirow[t]{4}{*}{ Add-on to MET + SU (NCT01392677) [78] } & 24 & $\geq 1 \mathrm{AE}$ & 51 & ND & 49 \\
\hline & & Genital & 0 & ND & 6 \\
\hline & & Urinary & 6 & ND & 6 \\
\hline & & Hypoglycemia & 4 & ND & 13 \\
\hline \multirow{4}{*}{$\begin{array}{l}\text { Dapagliflozin } 5 \text { mg combined with MET XR as } \\
\text { initial therapy (NCT00643851) [41] }\end{array}$} & 24 & $\geq 1 \mathrm{AE}$ & 59 & 69 & ND \\
\hline & & Genital & 2 & 7 & ND \\
\hline & & Urinary & 8 & 8 & ND \\
\hline & & Hypoglycemia & 0 & 3 & ND \\
\hline \multirow{4}{*}{$\begin{array}{l}\text { Dapagliflozin } 10 \text { mg combined with MET XR as } \\
\text { initial therapy (NCT00859898) [41] }\end{array}$} & 24 & $\geq 1 \mathrm{AE}$ & 57 & ND & 60 \\
\hline & & Genital & 2 & ND & 9 \\
\hline & & Urinary & 4 & ND & 8 \\
\hline & & Hypoglycemia & 3 & ND & 3 \\
\hline
\end{tabular}

*Hypoglycemia defined as symptoms suggestive of hypoglycemia or asymptomatic/symptomatic with plasma glucose $<63 \mathrm{mg} / \mathrm{dL}$.

$A E$, adverse event; $M E T$, metformin; ND, not determined; SU, sulfonylurea; $X R$, extended release. 
cardiovascular disease and hypertension, AEs were balanced across dapagliflozin and placebo groups [43]. The most common AEs in most studies were genital and urinary tract infections, headache, diarrhea, nasopharyngitis, and back pain [46-50].

Increased urinary excretion of glucose may increase the risk for genital and urinary tract infections [53]. Therefore, in the dapagliflozin clinical development program, signs and symptoms suggestive of such infections were defined prospectively, and patients were actively questioned about these symptoms at all study visits throughout the trials [46]. Across the trials, signs, symptoms, and other reports suggestive of genital infections and, in some trials, urinary tract infections, were more frequent in dapagliflozin-treated groups compared with placebo groups (Table 4). Events were of mild to moderate intensity. Infections were responsive to standard care, did not typically require interruption of dapagliflozin therapy, and rarely resulted in discontinuation of the studies [46-48].

In data pooled from 12 randomized trials (12- to 24-week duration), more patients treated with dapagliflozin $(2.5,5$, or $10 \mathrm{mg} / \mathrm{d}$ ) had diagnosed cases of genital infections (4\%-6\%) than did patients receiving placebo (1\%) [54]. Most cases were mild to moderate and responded to standard care. In these trials, percentages of patients reporting diagnosed cases of urinary tract infections were slightly higher with dapagliflozin (4\%-6\%) than with placebo (4\%) [55]. Most cases were mild to moderate and did not recur during the trial duration or result in interruption or discontinuation of dapagliflozin therapy.

Analyses of the eGFR from 12 placebo-controlled, randomized trials of $\leq 24$ weeks and from five trials of $\leq 102$ weeks found that the eGFR decreased at week 1, returned to baseline by week 24, and remained stable thereafter to week 102 in patients treated with dapagliflozin 5 or $10 \mathrm{mg} / \mathrm{d}$ [56]. It has been suggested that the acute reductions in eGFR with dapagliflozin may reflect reversible hemodynamic effects rather than permanent changes in renal function [16].

Events of hypoglycemia were infrequent and occurred at a similar rate with dapagliflozin as with placebo in the dapagliflozin monotherapy study [47], add-on to metformin studies [13,46], add-on to pioglitazone study [49], and addon to sitagliptin study (Table 4) [49,57]. The proportion of patients reporting hypoglycemic episodes was higher when dapagliflozin was added to a sulfonylurea $(7 \%-8 \%$ vs $5 \%$ with placebo) or insulin $(54 \%-56 \%$ vs $52 \%$ with placebo) $[48,50]$. In the add-on to insulin study, the proportion of patients with a major hypoglycemic event was low and similar across placebo (1.0\%) and dapagliflozin (0.9\%-1.5\%) groups. In the study in which dapagliflozin $10 \mathrm{mg} / \mathrm{d}$ was compared with glipizide as add-on therapy to metformin, the number of patients reporting hypoglycemic episodes was tenfold higher with glipizide (41\%) than with dapagliflozin (4\%) [40].

Dapagliflozin had variable effects on plasma lipids. Changes in LDL-C $(-0.5 \%$ to $+9.5 \%)$, HDL-C $(+2.1 \%$ to $+9.3 \%)$, and triglycerides $(-0.9 \%$ to $-10.6 \%)$ were noted in clinical trials [17].
In a pool of 13 placebo-controlled studies, the mean percentage change from baseline for total cholesterol after 24 weeks of treatment with dapagliflozin $10 \mathrm{mg}$ was $2.5 \%$ compared with $0 \%$ for placebo and for LDL-C was $-1.0 \%$ vs $2.9 \%$ [44].

In the clinical development program for dapagliflozin, an imbalance in bladder cancer was observed with dapagliflozin. Newly diagnosed bladder cancer was reported in $10 / 6045$ patients $(0.17 \%)$ treated with dapagliflozin and $1 / 3512$ patients $(0.03 \%)$ treated with placebo or comparator [58]. After excluding patients exposed to dapagliflozin for $<1$ year at the time of the diagnosis of bladder cancer, there were four cases of bladder cancer with dapagliflozin and no cases with placebo or comparator. Risk factors for bladder cancer and hematuria (a potential indicator of preexisting tumors) [59] at baseline were balanced between treatment groups. There were insufficient data to determine whether the cases of bladder cancer were related to dapagliflozin or whether dapagliflozin had an effect on preexisting bladder tumors. The incidence of bladder cancer with dapagliflozin is being monitored during an ongoing cardiovascular outcomes trial as well as through continued postmarketing surveillance [58]. Dapagliflozin should not be used in patients with active bladder cancer, and should be used with caution in those with a history of bladder cancer [30].

\section{Empagliflozin}

Empagliflozin (Jardiance ${ }^{\ddagger}$ ) was approved in the EU and US in 2014 [60]. The recommended starting dose is $10 \mathrm{mg} / \mathrm{d}$, which can be increased to $25 \mathrm{mg} /$ day [61]. Empagliflozin should not be used in patients with an eGFR $<45 \mathrm{~mL} / \mathrm{min} / 1.73 \mathrm{~m}^{2}$, and renal function should be monitored more frequently (at least yearly according to EU prescribing information) in patients with an eGFR $<60 \mathrm{~mL} / \mathrm{min} / 1.73 \mathrm{~m}^{2}$ [61,62]. In patients with T2DM, empagliflozin was absorbed rapidly with a mean $t_{1 / 2}$ of $10 \mathrm{~h}-19 \mathrm{~h}$ [63]. In healthy volunteers, empagliflozin pharmacokinetics were similar with and without coadministration of metformin, glimepiride, pioglitazone, sitagliptin, linagliptin, warfarin, verapamil, ramipril, simvastatin, hydrochlorothiazide, and torasemide [64].

\section{Efficacy}

In Phase III clinical trials, placebo-corrected mean changes from baseline in $\mathrm{HbA}_{1 \mathrm{c}}$ for empagliflozin 10 and $25 \mathrm{mg} / \mathrm{d}$ were $-0.74 \%$ to $-0.85 \%$ if used as monotherapy [65] and $-0.38 \%$ to $-0.64 \%$ if used as add-on therapy (Table 5) [66-69]. Empagliflozin also significantly reduced FPG (placebo-corrected change from baseline, -12 to $-36 \mathrm{mg} / \mathrm{dL}$ ) (Table 5) and 2-h PPG after a mixedmeal test (placebo-corrected change from baseline, -33 to $-52 \mathrm{mg} / \mathrm{dL}$ ) [66,67]. Placebo-corrected mean change in body weight with empagliflozin ranged from -1.6 to $-2.5 \mathrm{~kg}$ (Table 5). Across these clinical trials, empagliflozin consistently reduced SBP ( -2.9 to -5.2 vs 7 to $-2.9 \mathrm{mmHg}$ for placebo) and DBP

${ }^{\ddagger}$ Registered trademark of Boehringer Ingelheim Pharmaceuticals, Ridgefield, CT, USA 


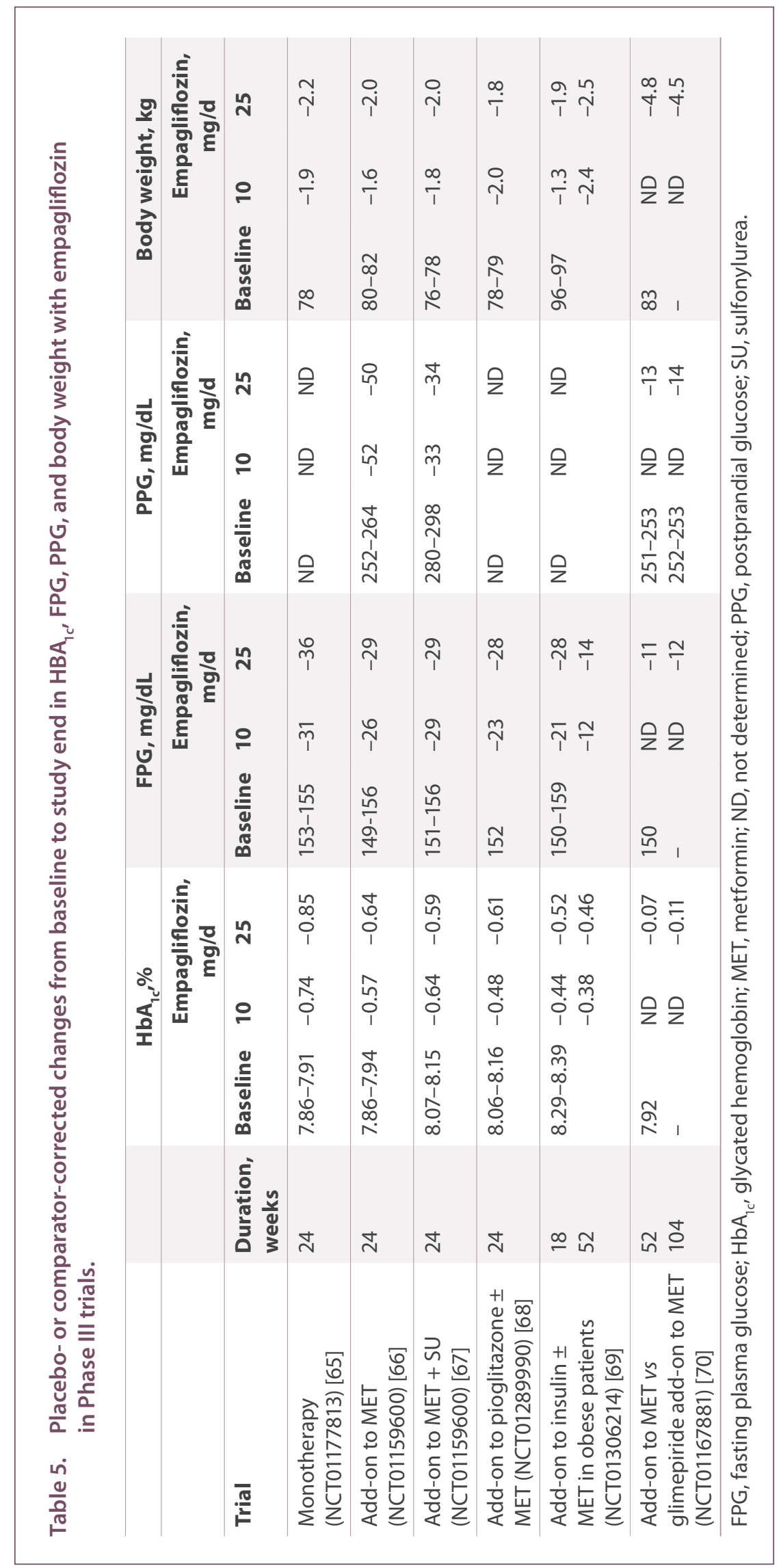


( -1.0 to -2.5 vs 0.3 to $-2.2 \mathrm{mmHg}$ for placebo) to a greater extent than placebo.

In a study comparing the effects of empagliflozin ( $25 \mathrm{mg} / \mathrm{d}$ ) compared with glimepiride (1-4 mg/d) as add-on therapy to metformin [70], empagliflozin was noninferior to glimepiride $(P<0.0001)$ with respect to the change in $\mathrm{HbA}_{1 \mathrm{c}}$ after 52 and 104 weeks of treatment (Table 5) and was superior to glimepiride at 104 weeks (difference vs glimepiride, $-0.11 \%$ ). Reduction in FPG was significantly $(P<0.0001)$ greater with empagliflozin compared with glimepiride at 52 and 104 weeks (Table 5). Patients receiving empagliflozin had a reduction from baseline in weight at 52 weeks $(-3.2 \mathrm{~kg})$ that was maintained at 104 weeks $(-3.1 \mathrm{~kg})$. Weight gains with glimepiride were reported at these two time points (1.6 and $1.3 \mathrm{~kg}$, respectively). Almost $90 \%$ of the weight loss with empagliflozin appeared to be the result of a reduction in fat mass (abdominal visceral and subcutaneous adipose tissue) [70]. Empagliflozin reduced SBP (-3.6 and $-3.1 \mathrm{mmHg}$ ) and DBP ( -1.9 and $-1.8 \mathrm{mmHg})$ at 52 and 104 weeks, whereas SBP $(+2.2$ and $+2.5 \mathrm{mmHg})$ and DBP (+0.9 and $+0.9 \mathrm{mmHg})$ were increased with glimepiride at these time points.

The efficacy and safety of empagliflozin compared with placebo added to existing antidiabetic drugs were assessed in patients with T2DM and stage-II (eGFR $\geq 60$ to $<90 \mathrm{~mL} / \mathrm{min} / 1.73 \mathrm{~m}^{2}$ ), stage-III ( $\geq 30$ to $<60 \mathrm{~mL} / \mathrm{min} / 1.73 \mathrm{~m}^{2}$ ), or stage-IV (eGFR $\geq 15$ to $<30 \mathrm{~mL} / \mathrm{min} / 1.73 \mathrm{~m}^{2}$ ) CKD [71]. In patients with stage-II CKD, empagliflozin (10 and $25 \mathrm{mg} / \mathrm{d}$ ) significantly reduced $\mathrm{HbA}_{1 \mathrm{c}}$ from baseline at 24 weeks compared with placebo (difference vs placebo $-0.52 \%$ and $-0.68 \%, P<0.0001$ for both). Both doses

Table 6. Adverse events, including genital infections and urinary tract infections and hypoglycemia,* with empagliflozin in Phase III trials.

\begin{tabular}{|c|c|c|c|c|c|}
\hline \multirow[b]{3}{*}{ Trial } & \multirow[b]{3}{*}{$\begin{array}{l}\text { Duration, } \\
\text { weeks }\end{array}$} & \multirow[b]{3}{*}{ AE } & \multicolumn{3}{|c|}{ Patients, \% } \\
\hline & & & \multirow[b]{2}{*}{$\begin{array}{l}\text { Placebo or } \\
\text { control }\end{array}$} & \multicolumn{2}{|c|}{$\begin{array}{c}\text { Empagliflozin, } \\
\text { mg/d }\end{array}$} \\
\hline & & & & 10 & 25 \\
\hline \multirow[t]{4}{*}{ Monotherapy (NCT01177813) [65] } & \multirow[t]{4}{*}{24} & $\geq 1 \mathrm{AE}$ & 61 & 55 & 61 \\
\hline & & Genital & 0 & 3 & 4 \\
\hline & & Urinary & 5 & 7 & 5 \\
\hline & & Hypoglycemia & $<1$ & $<1$ & $<1$ \\
\hline \multirow[t]{4}{*}{ Add-on to MET (NCT01159600) [66] } & \multirow[t]{4}{*}{24} & $\geq 1 \mathrm{AE}$ & 59 & 57 & 50 \\
\hline & & Genital & 0 & 4 & 5 \\
\hline & & Urinary & 5 & 5 & 6 \\
\hline & & Hypoglycemia & $<1$ & 2 & 1 \\
\hline \multirow{4}{*}{$\begin{array}{l}\text { Add-on to MET + SU } \\
\text { (NCT01159600) [67] }\end{array}$} & \multirow[t]{4}{*}{24} & $\geq 1 \mathrm{AE}$ & 63 & 68 & 64 \\
\hline & & Genital & 1 & 3 & 2 \\
\hline & & Urinary & 8 & 10 & 8 \\
\hline & & Hypoglycemia & 8 & 16 & 12 \\
\hline \multirow{4}{*}{$\begin{array}{l}\text { Add-on to pioglitazone } \pm \text { MET } \\
\text { (NCT01289990) [68] }\end{array}$} & \multirow[t]{4}{*}{24} & $\geq 1 \mathrm{AE}$ & 73 & 67 & 71 \\
\hline & & Genital & 2 & 9 & 4 \\
\hline & & Urinary & 16 & 17 & 12 \\
\hline & & Hypoglycemia & 2 & 1 & 2 \\
\hline \multirow{4}{*}{$\begin{array}{l}\text { Add-on to insulin } \pm \text { MET in obese } \\
\text { patients (NCT01306214) [69] }\end{array}$} & \multirow[t]{4}{*}{52} & $\geq 1 \mathrm{AE}$ & 90 & 86 & 85 \\
\hline & & Genital & 2 & 4 & 10 \\
\hline & & Urinary & 15 & 16 & 15 \\
\hline & & Hypoglycemia & 58 & 51 & 58 \\
\hline \multirow{4}{*}{$\begin{array}{l}\text { Add-on to MET vs glimepiride } \\
\text { add-on to MET (NCT01167881) [70] }\end{array}$} & \multirow[t]{4}{*}{104} & $\geq 1 \mathrm{AE}$ & 86 & ND & 86 \\
\hline & & Genital & 2 & ND & 12 \\
\hline & & Urinary & 13 & ND & 14 \\
\hline & & Hypoglycemia & 25 & ND & 4 \\
\hline
\end{tabular}

*Hypoglycemia defined by plasma glucose $\leq 70 \mathrm{mg} / \mathrm{dL}$ and/or requiring assistance.

$\mathrm{AE}$, adverse event; MET, metformin; ND, not determined; $\mathrm{SU}$, sulfonylurea. 
of empagliflozin also produced significant placebo-corrected reductions in FPG $(-20$ and $-24 \mathrm{mg} / \mathrm{dL})$, body weight $(-1.4$ and $-2.0 \mathrm{~kg})$, SBP $(-3.6$ and $-5.1 \mathrm{mmHg})$, and DBP $(-2.5$ and $-3.3 \mathrm{mmHg}$ ). Changes in glycemic measures, body weight, and BP were sustained at week 52. As expected, based on the mechanism of action of empagliflozin, the changes in glycemic and metabolic measures in patients with stage-III and -IV CKD were less than those in patients with stage-II CKD. In patients with stage-III CKD, empagliflozin ( $25 \mathrm{mg} / \mathrm{d}$ only) significantly reduced $\mathrm{HbA}_{1 \mathrm{c}}$ (difference vs placebo, $\left.-0.42 \%\right)$, FPG $(-20 \mathrm{mg} / \mathrm{dL})$, body weight $-0.9 \mathrm{~kg})$, SBP $(-4.3 \mathrm{mmHg})$, and DBP $(-1.9 \mathrm{mmHg})$ at week 24. These changes were sustained at 52 weeks of treatment. In patients with stage-IV CKD, empagliflozin (25 mg/d) had little or no effect on $\mathrm{HbA}_{1 \mathrm{c}}$ and FPG compared with placebo after 24 and 52 weeks of treatment. However, greater reductions in body weight ( -1.4 vs $-0.1 \mathrm{~kg})$, SBP (-7.4 vs $1.2 \mathrm{mmHg}$ ), and DBP (-2.4 vs $0.7 \mathrm{mmHg}$ ) occurred in patients receiving empagliflozin for 24 weeks than in those receiving placebo; these effects were sustained for 52 weeks.

\section{Safety}

Empagliflozin was, in general, well tolerated, with similar incidences of AEs in empagliflozin-treated groups and placebo groups (Table 6). As was observed with canagliflozin and dapagliflozin, genital infections were more common with empagliflozin than with placebo (Table 6). In most studies, hypoglycemic events were rare and similar across treatment groups. Hypoglycemia was more frequent with empagliflozin than with placebo when added to a sulfonylurea [67].

The overall incidence of AEs was similar with placebo and empagliflozin in patients with stage-II or -III CKD [71]. The proportion of patients with $\geq 1 \mathrm{AE}$ was higher with empagliflozin (92\%) than with placebo (84\%) in patients with stage-IV CKD. Hypoglycemia (38\% vs $32 \%$ ) as well as urinary tract infections (19\% vs $8 \%$ ) and genital infections ( $3 \%$ vs $0 \%$ ) were more common with empagliflozin than with placebo in patients with stage-IV CKD. Small decreases in the eGFR were observed with empagliflozin in patients with stage-II, -III, or -IV CKD. The eGFR returned to baseline three weeks after treatment completion in all CKD groups.

Most studies reported a small increase in HDL-C and no change in triglycerides with empagliflozin compared with placebo $[65-68,70]$. Small increases $[66,70]$ or no change in LDL-C were noted with empagliflozin [65,67-69].

\section{Implications for healthcare providers}

The integration of lifestyle management, appropriate self-care, and medication adherence is vital to the successful addition of SGLT2 therapies into the antidiabetic regimen. The American Association of Diabetes Educators recognizes seven self-care behaviors that are critical in DM self-management: (i) monitoring, (ii) taking medication, (iii) being active, (iv) eating a healthy diet, (v) problem solving, (vi) healthy coping, and (vii) reducing risk factors [6]. Healthcare providers can play a pivotal part in improving adherence to therapy and support the efforts of other members of the healthcare team in helping patients with T2DM attain and maintain glycemic goals [72-74].

SGLT2 inhibitors are a new class of agents and most patients may not know the difference between classes. Hence, it is important that healthcare providers explain the unique mechanism of action of these drugs and how to identify, take, and store these medications. Healthcare providers should inform patients about the risk of developing genital infections and urinary tract infections. As the number of patients taking SGLT2 inhibitors increases, healthcare providers will play a very important part in helping patients maintain medication adherence and approach their $\mathrm{HbA}_{1 c}$ goals.

\section{Summary}

Canagliflozin, dapagliflozin, and empagliflozin are medications from the novel SGLT2 inhibitor class that offer a unique treatment option for T2DM that is independent of the secretion or action of insulin. The AACE recommends that SGLT2 inhibitors be considered as a monotherapy option in patients for whom metformin is contraindicated or not tolerated [4]. In addition, SGLT2 inhibitors may be an option as add-on therapy to metformin or another first-line agent as part of dual or triple therapy. Canagliflozin, dapagliflozin, and empagliflozin reduce $\mathrm{HbA}_{1 \mathrm{c}^{\prime}}$ FPG, and PPG (Table 7) in patients across various stages of T2DM by promoting removal of excess glucose via increased

Table 7. Summary of effects of SGLT2 inhibitors.

\begin{tabular}{|c|c|}
\hline Parameter & Response \\
\hline $\mathrm{HbA}_{1 \mathrm{c}}$ & I \\
\hline FPG & $\downarrow$ \\
\hline PPG & I \\
\hline Body weight & $\downarrow$ \\
\hline Blood pressure & $\downarrow$ \\
\hline \multicolumn{2}{|l|}{ Lipids } \\
\hline LDL-C & $\mathbf{t}$ \\
\hline $\mathrm{HDL}-\mathrm{C}$ & $\mathbf{t}$ \\
\hline Triglycerides & tlor $\Leftrightarrow$ \\
\hline \multicolumn{2}{|l|}{ Infections } \\
\hline Genital & $\mathbf{t}$ \\
\hline Urinary tract & t or $\Leftrightarrow$ \\
\hline
\end{tabular}

FPG, fasting plasma glucose; $\mathrm{HbA}_{1 c^{\prime}}$ glycated hemoglobin; HDL-C, high-density lipoprotein cholesterol; LDL-C, low-density lipoprotein cholesterol; PPG, postprandial glucose; SGLT2, sodium-glucose co-transporter 2 . 
urinary excretion of glucose. In addition, they are complementary to existing antihyperglycemic agents and improve glycemic control in elderly patients and in patients inadequately controlled with metformin, sulfonylurea, thiazolidinedione, dipeptidyl peptidase-4 inhibitors, or insulin or who are treatment naïve. The weight loss associated with SGLT2 inhibitors may be a benefit to overweight and obese patients with T2DM, and may attenuate the weight gains characteristic of some other therapeutic options. SGLT2 inhibitors also cause modest reductions in BP, probably as a result of weight loss and diuretic action. Increases in HDL-C and minor changes in triglycerides were noted in most clinical trials. However, increases in LDL-C were also noted and need to be monitored and treated. Canagliflozin, dapagliflozin, and empagliflozin were, in general, well tolerated in clinical trials and, as expected based on their mechanism of action, the frequency of hypoglycemia was low except if taken with insulin or an insulin secretagogue. There were increased episodes of genital infections and, in some trials, urinary tract infections, with these agents. These infections were, in general, mild to moderate and resolved with standard treatment. These SGLT2 inhibitors should not be used in patients with impaired renal function (eGFR: $<45 \mathrm{~mL} / \mathrm{min} / 1.73 \mathrm{~m}^{2}$ for canagliflozin and empagliflozin, $<60 \mathrm{~mL} / \mathrm{min} / 1.73 \mathrm{~m}^{2}$ for dapagliflozin).

\section{Conclusion}

SGLT2 inhibitors are new insulin-independent agents that, given adequate renal function, improve glycemic control in patients with T2DM not adequately controlled by diet and exercise or by other antidiabetic agents. Canagliflozin, dapagliflozin, and empagliflozin also provide reductions in body weight and BP. The most common adverse effects are genital infections and urinary tract infections. Further studies are being conducted to assess the effects of these drugs on cardiovascular outcomes. SGLT2 inhibitors are a promising new treatment option for T2DM.

\section{Contributions}

The author participated in the preparation, review, editing, and final approval of the manuscript.

\section{Potential conflicts of interest}

The International Committee of Medical Journal Editors' (ICMJE) Potential Conflicts of Interests form for the author is summarized below. The original form is available for download at: http://www.drugsincontext.com/wp-content/ uploads/2014/12/dic.212264-COI.pdf

\section{Funding declaration}

The author reports no competing financial interests. The author did not receive any financial or monetary transfer of value for the writing of this manuscript.

\section{Acknowledgments}

Editorial support was provided by Richard M Edwards, PhD, and Janet E Matsuura, PhD, from Complete Healthcare Communications, Inc., and was funded by Bristol-Myers Squibb and AstraZeneca.

\section{References}

1. Centers for Disease Control and Prevention. National diabetes statistics report: estimates of diabetes and its burden in the United States, 2014. Available at: http://www.cdc.gov/diabetes/pubs/statsreport14/nationaldiabetes-report-web.pdf. [Last accessed September 23, 2014].

2. Stratton IM, Adler Al, Neil HA et al. Association of glycaemia with macrovascular and microvascular complications of type 2 diabetes (UKPDS 35): prospective observational study. BMJ 2000;321(7258):405-12. http://dx.doi.org/10.1136/bmj.321.7258.405

3. American Diabetes Association. Standards of medical care in diabetes-2014. Diabetes Care 2014;37(suppl 1):S14-S80. http://dx.doi.org/10.2337/dc14-S014

4. Garber AJ, Abrahamson MJ, Barzilay Jl et al. American Association of Clinical Endocrinologists' comprehensive diabetes management algorithm 2013 consensus statementexecutive summary. Endocr Pract 2013;19(3):536-57. http://dx.doi.org/10.4158/EP13176.CS

5. Nathan DM, Buse JB, Davidson MB et al. Medical management of hyperglycemia in type 2 diabetes: a consensus algorithm for the initiation and adjustment of therapy: a consensus statement of the American Diabetes Association and the European Association for the Study of Diabetes. Diabetes Care 2009;32(1):193-203. http://dx.doi.org/10.2337/dc08-9025

6. Stark Casagrande S, Fradkin JE, Saydah SH, Rust KF, Cowie CC. The prevalence of meeting A1C, blood pressure, and LDL goals among people with diabetes, 1988-2010. Diabetes Care 2013;36(8):2271-9. http://dx.doi.org/10.2337/dc12-2258

7. Pfister M, Whaley JM, Zhang L, List JF. Inhibition of SGLT2: a novel strategy for treatment of type 2 diabetes mellitus. Clin Pharmacol Ther 2011;89(4):621-5. http://dx.doi.org/10.1038/clpt.2011.16

8. Mather A, Pollock C. Glucose handling by the kidney. Kidney Int 2011;79(suppl 120):S1-S6. http://dx.doi.org/10.1038/ki.2010.509

9. DeFronzo RA, Hompesch M, Kasichayanula S et al. Characterization of renal glucose reabsorption in response to dapagliflozin in healthy subjects and subjects with type 2 diabetes. Diabetes Care 2013;36(10):3169-76. http://dx.doi.org/10.2337/dc13-0387

10. Rahmoune H, Thompson PW, Ward JM, Smith CD, Hong G, Brown J. Glucose transporters in human renal proximal tubular cells isolated from the urine of patients with 
non-insulin-dependent diabetes. Diabetes

2005;54(12):3427-34.

http://dx.doi.org/10.2337/diabetes.54.12.3427

11. Gerich JE. Role of the kidney in normal glucose homeostasis and in the hyperglycaemia of diabetes mellitus: therapeutic implications. Diabet Med 2010;27(2):136-42.

http://dx.doi.org/10.1111/j.1464-5491.2009.02894.x

12. List JF, Whaley JM. Glucose dynamics and mechanistic implications of SGLT2 inhibitors in animals and humans. Kidney Int 2011;79(suppl 120):S20-S7. http://dx.doi.org/10.1038/ki.2010.512

13. Bolinder J, Ljunggren $O$, Kullberg J et al. Effects of dapagliflozin on body weight, total fat mass, and regional adipose tissue distribution in patients with type 2 diabetes mellitus with inadequate glycemic control on metformin. J Clin Endocrinol Metab 2012;97(3):1020-31. http://dx.doi.org/10.1210/jc.2011-2260

14. Cefalu WT, Leiter LA, Yoon KH et al. Efficacy and safety of canagliflozin versus glimepiride in patients with type 2 diabetes inadequately controlled with metformin (CANTATA-SU): 52 week results from a randomised, double-blind, phase 3 non-inferiority trial. Lancet 2013;382(9896):941-50. http://dx.doi.org/10.1016/S0140-6736(13)60683-2

15. Eckel RH, Kahn SE, Ferrannini E et al. Obesity and type 2 diabetes: what can be unified and what needs to be individualized? Diabetes Care 2011;34(6):1424-30. http://dx.doi.org/10.2337/dc11-0447

16. Lambers Heerspink HJ, de Zeeuw D, Wie L, Leslie B, List J. Dapagliflozin a glucose-regulating drug with diuretic properties in subjects with type 2 diabetes. Diabetes Obes Metab 2013;15(9):853-62.

http://dx.doi.org/10.1111/dom.12127

17. Ptaszynska A, Hardy E, Johnsson E, Parikh S, List J. Effects of dapagliflozin on cardiovascular risk factors. Postgrad Med 2013;125(3):181-9. http://dx.doi.org/10.3810/pgm.2013.05.2667

18. Invokana ${ }^{\circledast}$ (canagliflozin). Full Prescribing Information, Janssen Pharmaceuticals, Titusville, NJ, 2013.

19. Devineni $D$, Curtin CR, Polidori $D$ et al. Pharmacokinetics and pharmacodynamics of canagliflozin, a sodium glucose co-transporter 2 inhibitor, in subjects with type 2 diabetes mellitus. J Clin Pharmacol 2013;53(6):601-10.

http://dx.doi.org/10.1002/jcph.88

20. Sha S, Devineni D, Ghosh A et al. Canagliflozin, a novel inhibitor of sodium glucose co-transporter 2, dose dependently reduces calculated renal threshold for glucose excretion and increases urinary glucose excretion in healthy subjects. Diabetes Obes Metab 2011;13(7):669-72. http://dx.doi.org/10.1111/j.1463-1326.2011.01406.x

21. Grempler R, Thomas L, Eckhardt M et al. Empagliflozin, a novel selective sodium glucose cotransporter-2 (SGLT-2) inhibitor: characterisation and comparison with other
SGLT-2 inhibitors. Diabetes Obes Metab 2012;14(1):83-90. http://dx.doi.org/10.1111/j.1463-1326.2011.01517.x

22. Wright EM, Hirayama BA, Loo DF. Active sugar transport in health and disease. J Intern Med 2007;261(1):32-43. http://dx.doi.org/10.1111/j.1365-2796.2006.01746.x

23. Polidori D, Sha S, Mudaliar S et al. Canagliflozin lowers postprandial glucose and insulin by delaying intestinal glucose absorption in addition to increasing urinary glucose excretion: results of a randomized, placebocontrolled study. Diabetes Care 2013;36(8):2154-61. http://dx.doi.org/10.2337/dc12-2391

24. Lavalle-Gonzalez FJ, Januszewicz A, Davidson J et al. Efficacy and safety of canagliflozin compared with placebo and sitagliptin in patients with type 2 diabetes on background metformin monotherapy: a randomised trial. Diabetologia 2013;56(12):2582-92.

http://dx.doi.org/10.1007/s00125-013-3039-1

25. Schernthaner G, Gross JL, Rosenstock J et al. Canagliflozin compared with sitagliptin for patients with type 2 diabetes who do not have adequate glycemic control with metformin plus sulfonylurea: a 52-week randomized trial. Diabetes Care 2013;36(9):2508-15. http://dx.doi.org/10.2337/dc12-2491

26. Bode B, Stenlof K, Sullivan D, Fung A, Usiskin K. Efficacy and safety of canagliflozin treatment in older subjects with type 2 diabetes mellitus: a randomized trial. Hosp Pract (1995). 2013;41(2):72-84. http://dx.doi.org/10.3810/hp.2013.04.1020

27. Yale JF, Bakris G, Cariou B et al. Efficacy and safety of canagliflozin in subjects with type 2 diabetes and chronic kidney disease. Diabetes Obes Metab 2013;15(5):463-73. http://dx.doi.org/10.1111/dom.12090

28. Stenlof K, Cefalu WT, Kim KA et al. Efficacy and safety of canagliflozin monotherapy in subjects with type 2 diabetes mellitus inadequately controlled with diet and exercise. Diabetes Obes Metab 2013;15(4):372-82. http://dx.doi.org/10.1111/dom.12054

29. Weir MR, Kline I, Xie J, Edwards R, Usiskin K. Effect of canagliflozin on serum electrolytes in patients with type 2 diabetes in relation to estimated glomerular filtration rate (eGFR). Curr Med Res Opin 2014;30(9):1759-68. http://dx.doi.org/10.1185/03007995.2014.919907

30. Farxiga ${ }^{\circledR}$ (dapagliflozin). Full Prescribing Information, Bristol-Myers Squibb and AstraZeneca, Princeton, NJ, and Wilmington, DE, USA, 2014.

31. Forxiga, summary of product characteristics. Available at: http://www.forxiga.eu/sites/default/files/Forxiga\%20 Summary\%20of\%20Product $\% 20$ CharacteristicsSmPC.pdf. [Last accessed September 23, 2014].

32. Komoroski B, Vachharajani N, Boulton D et al. Dapagliflozin, a novel SGLT2 inhibitor, induces dose-dependent glucosuria in healthy subjects. Clin Pharmacol Ther 2009;85(5):520-6. http://dx.doi.org/10.1038/clpt.2008.251

33. Obermeier M, Yao M, Khanna A et al. In vitro characterization and pharmacokinetics of dapagliflozin 
(BMS-512148), a potent sodium-glucose cotransporter type II inhibitor, in animals and humans. Drug Metab Dispos 2010;38(3):405-14.

http://dx.doi.org/10.1124/dmd.109.029165

34. Kasichayanula S, Liu X, Zhang W et al. Effect of a high-fat meal on the pharmacokinetics of dapagliflozin, a selective SGLT2 inhibitor, in healthy subjects. Diabetes Obes Metab 2011;13(8):770-3. http://dx.doi.org/10.1111/j.1463-1326.2011.01397.x

35. Kasichayanula S, Liu X, Shyu WC et al. Lack of pharmacokinetic interaction between dapagliflozin, a novel sodium-glucose transporter 2 inhibitor, and metformin, pioglitazone, glimepiride or sitagliptin in healthy subjects. Diabetes Obes Metab 2011;13(1):47-54. http://dx.doi.org/10.1111/j.1463-1326.2010.01314.x

36. Kasichayanula S, Chang M, Liu X et al. Lack of pharmacokinetic interactions between dapagliflozin and simvastatin, valsartan, warfarin, or digoxin. Adv Ther 2012;29(2):163-77. http://dx.doi.org/10.1007/s12325-011-0098-x

37. Bailey CJ, Gross JL, Hennicken D, lqbal N, Mansfield TA, List JF. Dapagliflozin add-on to metformin in type 2 diabetes inadequately controlled with metformin: a randomized, double-blind, placebocontrolled 102-week trial. BMC Med 2013;11:43. http://dx.doi.org/10.1186/1741-7015-11-43

38. Bolinder J, Ljunggren $\mathrm{O}$, Johansson L et al. Dapagliflozin maintains glycaemic control while reducing weight and body fat mass over 2 years in patients with type 2 diabetes mellitus inadequately controlled on metformin. Diabetes Obes Metab 2014;16(2):159-69. http://dx.doi.org/10.1111/dom.12189

39. Wilding JP, Woo V, Rohwedder K, Sugg J, Parikh S. Dapagliflozin in patients with type 2 diabetes receiving high doses of insulin: efficacy and safety over two years. Diabetes Obes Metab 2014;16(2):124-36. http://dx.doi.org/10.1111/dom.12187

40. Nauck MA, Del Prato S, Meier JJ et al. Dapagliflozin versus glipizide as add-on therapy in patients with type 2 diabetes who have inadequate glycemic control with metformin: a randomized, 52-week, double-blind, active-controlled noninferiority trial. Diabetes Care 2011;34(9):2015-22. http://dx.doi.org/10.2337/dc11-0606

41. Henry RR, Murray AV, Marmolejo MH, Hennicken D, Ptaszynska A, List JF. Dapagliflozin, metformin XR, or both: initial pharmacotherapy for type 2 diabetes, a randomised controlled trial. Int J Clin Pract 2012;66(5):446-56. http://dx.doi.org/10.1111/j.1742-1241.2012.02911.x

42. Leiter LA, Cefalu WT, de Bruin TW, Gause-Nilsson I, Sugg JE, Parikh S. Dapagliflozin added to usual care in individuals with type 2 diabetes mellitus with preexisting cardiovascular disease: a 24-week, multicenter, randomized, double-blind, placebo-controlled study with a 28-week extension. J Am Geriatr Soc 2014;62(7):1252-62. http://dx.doi.org/10.1111/jgs.12881
43. Cefalu WT, Leiter LA, de Bruin TW, Gause-Nilsson I, Sugg JE, Parikh S. Dapagliflozin treatment for type 2 diabetes mellitus patients with comorbid cardiovascular disease and hypertension [abstract]. Diabetes 2012;61(suppl 1):A271.

44. Kohan DE, Fioretto P, Tang W, List JF. Long-term study of patients with type 2 diabetes and moderate renal impairment shows that dapagliflozin reduces weight and blood pressure but does not improve glycemic control. Kidney Int 2014;85(4):962-71.

http://dx.doi.org/10.1038/ki.2013.356

45. Kasichayanula S, Liu X, Pe Benito M et al. The influence of kidney function on dapagliflozin exposure, metabolism and pharmacodynamics in healthy subjects and in patients with type 2 diabetes mellitus. Br J Clin Pharmacol 2013;76(3):432-44. http://dx.doi.org/10.1111/bcp.12056

46. Bailey CJ, Gross JL, Pieters A, Bastien A, List JF. Effect of dapagliflozin in patients with type 2 diabetes who have inadequate glycaemic control with metformin: a randomised, double-blind, placebo-controlled trial. Lancet 2010;375(9733):2223-33. http://dx.doi.org/10.1016/S0140-6736(10)60407-2

47. Ferrannini E, Ramos SJ, Salsali A, Tang W, List JF. Dapagliflozin monotherapy in type 2 diabetic patients with inadequate glycemic control by diet and exercise: a randomized, double-blind, placebo-controlled, phase 3 trial. Diabetes Care 2010;33(10):2217-24 . http://dx.doi.org/10.2337/dc10-0612

48. Strojek K, Yoon KH, Hruba V, Elze M, Langkilde AM, Parikh S. Effect of dapagliflozin in patients with type 2 diabetes who have inadequate glycaemic control with glimepiride: a randomized, 24-week, double-blind, placebo-controlled trial. Diabetes Obes Metab 2011;13(10):928-38. http://dx.doi.org/10.1111/j.1463-1326.2011.01434.x

49. Rosenstock J, Vico M, Wei L, Salsali A, List JF. Effects of dapagliflozin, an SGLT2 inhibitor, on $\mathrm{HbA}_{1 c^{\prime}}$ body weight, and hypoglycemia risk in patients with type 2 diabetes inadequately controlled on pioglitazone monotherapy. Diabetes Care 2012;35(7):1473-8. http://dx.doi.org/10.2337/dc11-1693

50. Wilding JPH, Woo V, Soler NG et al. Long-term efficacy of dapagliflozin in patients with type 2 diabetes mellitus receiving high doses of insulin: a randomized trial. Ann Intern Med 2012;156(6):405-15. http://dx.doi.org/10.7326/0003-4819-156-6-201203200-00003

51. Weber MA, Mansfield TA, Alessi F, Ptaszynska A. Effects of dapagliflozin on blood pressure in diabetic patients with hypertension inadequately controlled by a reninangiotensin system blocker [abstract]. Circulation 2013;128(suppl 22):A13144.

52. Weber MA, Mansfield TA, T'joen C, Ptaszynska A. Dapagliflozin for reduction of blood pressure in diabetic patients inadequately controlled with combination antihypertensive regimen [abstract]. Circulation 2013;128(suppl 22):A13165. 
53. Hoepelman AIM, Meiland R, Geerlings SE. Pathogenesis and management of bacterial urinary tract infections in adult patients with diabetes mellitus. Int J Antimicrob Agents 2003;22(suppl 2):35-43. http://dx.doi.org/10.1016/S0924-8579(03)00234-6

54. Johnsson KM, Ptaszynska A, Schmitz B, Sugg J, Parikh SJ, List JF. Vulvovaginitis and balanitis in patients with diabetes treated with dapagliflozin. J Diabetes Complications 2013;27(5):479-84. http://dx.doi.org/10.1016/j.jdiacomp.2013.04.012

55. Johnsson KM, Ptaszynska A, Schmitz B, Sugg J, Parikh SJ, List JF. Urinary tract infections in patients with diabetes treated with dapagliflozin. J Diabetes Complications 2013;27(5):473-8. http://dx.doi.org/10.1016/j.jdiacomp.2013.05.004

56. Ptaszynska A, Chalamandaris A, Sugg JE et al. Effect of dapagliflozin on renal function [abstract]. Diabetes 2012;61(suppl 1):A283.

57. Jabbour SA, Hardy E, Sugg J, Parikh S, Study 10 Group. Dapagliflozin is effective as add-on therapy to sitagliptin with or without metformin: a 24-week, multicenter, randomized, double-blind, placebocontrolled study. Diabetes Care 2014;37(3):740-50. http://dx.doi.org/10.2337/dc13-0467

58. US Food and Drug Administration. FDA briefing document. Dapagliflozin oral tablets, 5 and $10 \mathrm{mg}$. December 12, 2013. Available at: http://www.fda.gov/downloads/AdvisoryCommittees/ CommitteesMeetingMaterials/Drugs/ EndocrinologicandMetabolicDrugsAdvisoryCommittee/ UCM378076.pdf. [Last accessed September 22, 2014].

59. Griffiths TR, on behalf of Action on Bladder Cancer. Current perspectives in bladder cancer management. Int J Clin Pract 2013;67(5):435-48. http://dx.doi.org/10.1111/ijcp.12075

60. Neumiller JJ. Empagliflozin: a new sodium-glucose co-transporter 2 (SGLT2) inhibitor for the treatment of type 2 diabetes. Drugs Context 2014;3:212262. http://dx.doi.org/10.7573/dic.212262

61. Jardiance ${ }^{\circledR}$ (empagliflozin). Full Prescribing Information, Boehringer Ingelheim Pharmaceuticals and Eli Lilly and Company, Ingelheim, Germany, and Indianapolis, IN, USA, 2014.

62. Jardiance ${ }^{\circledast}$. Summary of product characteristics. Available at: http://www.ema.europa.eu/docs/en_GB/document_ library/EPAR_-_Product_Information/human/002677/ WC500168592.pdf. [Last accessed September 29, 2014].

63. Heise T, Seman L, Macha S et al. Safety, tolerability, pharmacokinetics, and pharmacodynamics of multiple rising doses of empagliflozin in patients with type 2 diabetes mellitus. Diabetes Ther 2013;4(2):331-45. http://dx.doi.org/10.1007/s13300-013-0030-2

64. Scheen AJ. Pharmacokinetic and pharmacodynamic profile of empagliflozin, a sodium glucose co-transporter 2 inhibitor. Clin Pharmacokinet 2014;53(3):213-25. http://dx.doi.org/10.1007/s40262-013-0126-x
65. Roden M, Weng J, Eilbracht J et al. Empagliflozin monotherapy with sitagliptin as an active comparator in patients with type 2 diabetes: a randomised, double-blind, placebo-controlled, phase 3 trial. Lancet Diabetes Endocrinol 2013;1(3):208-19. http://dx.doi.org/10.1016/S2213-8587(13)70084-6

66. Häring $\mathrm{H}-\mathrm{U}$, Merker L, Seewaldt-Becker E et al. Empagliflozin as add-on to metformin in patients with type 2 diabetes: a 24-week, randomized, double-blind, placebo-controlled trial. Diabetes Care 2014;37(6):1650-9.

http://dx.doi.org/10.2337/dc13-2105

67. Häring H-U, Merker L, Seewaldt-Becker E et al. Empagliflozin as add-on to metformin plus sulfonylurea in patients with type 2 diabetes: a 24-week, randomized, double-blind, placebocontrolled trial. Diabetes Care 2013;36(11):3396-404. http://dx.doi.org/10.2337/dc12-2673

68. Kovacs CS, Seshiah V, Swallow R et al. Empagliflozin improves glycaemic and weight control as add-on therapy to pioglitazone or pioglitazone plus metformin in patients with type 2 diabetes: a 24-week, randomized, placebo-controlled trial. Diabetes Obes Metab 2014;16(2):147-58. http://dx.doi.org/10.1111/dom.12188

69. Rosenstock J, Jelaska A, Frappin G et al. Improved glucose control with weight loss, lower insulin doses, and no increased hypoglycemia with empagliflozin added to titrated multiple daily injections of insulin in obese inadequately controlled type 2 diabetes. Diabetes Care 2014;37(7):1815-23.

http://dx.doi.org/10.2337/dc13-3055

70. Ridderstråle M, Andersen KR, Zeller C, Kim G, Woerle HJ, Broedl UC. Comparison of empagliflozin and glimepiride as add-on to metformin in patients with type 2 diabetes: a 104-week randomised, active-controlled, double-blind, phase 3 trial. Lancet Diabetes Endocrinol 2014;2(9):691-700. http://dx.doi.org/10.1016/S2213-8587(14)70120-2

71. Barnett AH, Mithal A, Manassie J et al. Efficacy and safety of empagliflozin added to existing antidiabetes treatment in patients with type 2 diabetes and chronic kidney disease: a randomised, double-blind, placebo-controlled trial. Lancet Diabetes Endocrinol 2014;2(5):369-84. http://dx.doi.org/10.1016/S2213-8587(13)70208-0

72. Glasgow RE, Emont S, Miller DC. Assessing delivery of the five 'As' for patient-centered counseling. Health Promot Int 2006;21(3):245-55. http://dx.doi.org/10.1093/heapro/dal017

73. Joy SV. Clinical pearls and strategies to optimize patient outcomes. Diabetes Educ 2008;34(suppl 3):54S-9S http://dx.doi.org/10.1177/0145721708319233

74. Martin C, Daly A, McWhorter LS, Shwide-Slavin C, Kushion W. The scope of practice, standards of practice, and standards of professional performance for diabetes educators. Diabetes Educ 2005;31(4):487-8, 490, 492. http://dx.doi.org/10.1177/0145721705279719 
75. Wilding JP, Charpentier G, Hollander P et al. Efficacy and safety of canagliflozin in patients with type 2 diabetes mellitus inadequately controlled with metformin and sulphonylurea: a randomised trial. Int J Clin Pract 2013;67(12):1267-82.

http://dx.doi.org/10.1111/ijcp.12322

76. Rosenstock J, Davies MJ, Dumas R et al. Effects of canagliflozin added on to basal insulin +/- other antihyperglycemic agents in type 2 diabetes [abstract]. Diabetes 2013;62(suppl 1):A280.
77. Forst T, Guthrie R, Goldenberg R et al. Efficacy and safety of canagliflozin over 52 weeks in patients with type 2 diabetes on background metformin and pioglitazone. Diabetes Obes Metab 2014;16(5):467-77. http://dx.doi.org/10.1111/dom.12273

78. Matthaei S, Rohwedder K, Grohl A, Johnsson E. Dapagliflozin improves glycaemic control and reduces body weight as add-on therapy to metformin plus sulphonylurea. Presented at: European Association for the Study of Diabetes, September 23-27, 2013; Barcelona, Spain. 